\title{
Special Functions of the Teachers College Libraries
}

Mr. Watson is librarian, Northwestern State College of Louisiana, Natchitoches.

A $S$ WE all know, soon after our nation $\Lambda_{\text {was brought into being, its founders }}$ realized that if their "great experiment in democracy" was to endure, some effective method of educating the masses would have to be found. During the early part of the nineteenth century there was a sufficient number of common (i.e., elementary) schools to provide a basic education for all of the people; but, inasmuch as most of the teachers were almost wholly lacking in adequate training, the type of instruction offered in these schools was very poor in quality.

In order to provide facilities for training prospective teachers, numerous abortive attempts were made to establish and maintain municipal monitorial schools; but it was not until 1839 that the first publiclysupported normal school was established, at Lexington, Mass. It was so successful that I4 more such schools were established before the outbreak of the Civil War.

Despite the fine work that these schools have done, however, during the last 60 years normals have been found increasingly inadequate for the preparing of suitablyqualified teachers. As a result of this developing situation, the New York Normal School, which had been founded in 1844 , reorganized in 1890 as a college; and in I897 Michigan State Normal School became Michigan State Normal College. So many other institutions have followed the example of these two pioneers that during the twentieth century, normal schools have virtually disappeared. Of the 2 Io teachertraining institutions listed in the Education Directory for $1948-49,{ }^{1}$ only I 3 do not have complete four-year college programs (we must remember, however, that the Directory does not include all of the teacher-training institutions.)

The rapid multiplication of teachers colleges and their increasing importance led to the establishment in 1917 of The American Association of Teachers Colleges (recently renamed The American Associations of Colleges for Teacher Education). A program of accrediting began in 1927. The first formal set of standards for teachers colleges was adopted by this association in I93I, and these standards were revised in 1947. Thus, the teachers colleges of today form a distinct group of professional schools, and they are making a vital contribution to the national welfare. ${ }^{2}$

There are, therefore, historical reasons for the origin and development of the teachers college, its function being twofold : it must produce people who lead full and enriched lives-thinkers, doers, leaders;

1 Education Directory, I948-49, Part 3. Washington, U. S. Government Printing Office, I 948 , p.7. (U. S Federal Security Agency, Office of Education). The difference in figures in form three in Mr. Burke's paper is a result of a change in the method of classifying institutions. (Editor's Note.)

2 In considering the whole question of teacher-training, one must not overlook the fact that during the last halfcentury some 79 departments or schools of education have been created in universities; and a large proportion of the colleges that have primary aims other than that of training teachers do actually offer courses in education. We must also bear in mind the fact that about half of the must also bear in mind the fact that about half of the
teachers colleges have broadened their curricula to such an extent that they approximate those of liberal arts colleges or colleges of applied arts and sciences. 
and, in addition, it must train its students effectively in the techniques of imparting knowledge to others and of teaching others to think and to take their proper places in our complex modern civilization.

In like manner, the function of the library in the teachers college is twofold. In addition to carrying on all of the functions of the library which serves a liberal arts college $^{3}$ the teachers college library must provide special services to the college department of education in its work of training teachers.

These special services may be enumerated as follows:

I. The provision of books, periodicals, audiovisual aids and other materials in the field of professional education.

2. The maintenance of a textbook exhibit.

3. The maintenance of a demonstration school library.

4. The offering of courses in library science.

5. The provision of service to graduate students.

6. The provision of services to correspondence and extension students.

7. The giving of service to alumni.

I. Of these services, the first-named may not seem to be a special service, inasmuch as any well-rounded book collection will have a number of works in the fields of pure and applied psychology, and may even have materials on the history of education. But these books will constitute a relatively small percentage of the collection, whereas the teachers college must, of necessity, have extensive holdings in these fields. According to the recent comprehensive survey made by Fairchild, ${ }^{4}$ education and psychology books constitute almost one-fifth

3 Lyle, G. R. The Administration of the College Library. 2d ed. New York, Wilson, r949. p.24-25.

4 Fairchild, R. W., and others. "The Organization and Administration of Teachers College Libraries." Twenty-Second Yearbook of the American Association of Teachers Colleges. Oneonta, New York, American Association of Teachers Colleges, 1943. p.68. of the total collection of the average teachers college library.

2. The volumes comprising a textbook exhibit should not be cataloged and incorporated into the main collection, but should be shelved together in a place where they can be examined freely by the prospective teachers.

Exhibits usually consist primarily of gift copies of currently available high school and elementary school texts; but in some instances, where free copies are not available, books may well be acquired through purchase.

Unfortunately, textbook exhibits are not found in all teachers college libraries. In fact, the Fairchild report ${ }^{5}$ on the libraries in the 165 colleges accredited by the Association of Colleges for Teacher Education shows that only 16 per cent have exhibits. Rosenlof ${ }^{6}$ urges that every teachers college library maintain a textbook exhibit; and there seems to be very good reason for believing that his advice is sound and that such exhibits perform a valuable function, even in those states that have state-adopted textbooks and centralized purchasing.

3. The third function to engage our attention is the provision of a demonstration school library. Ideally, there should be on every teachers college campus two demonstration schools and libraries-one for the elementary level and one for the secondary. I do not have any information regarding the situation in the United States as a whole, but I have the results of a survey which Campbell ${ }^{7}$ made in 1948 of the teachers colleges in the northwestern area of the nation. Although sweeping generalizations can be a little risky, I be-

\footnotetext{
Ibid. p.63.

6 Rosenlof, G. W. Library Facilities of Teacher Train ing Institutions. New York, Columbia University Press, I 929 . p. 69 .

TCampbell, Ronald. "Campus School and StudentTeaching Arrangement at Seventeen Schools." Educa tion Administration and Supervision, 34:165, March 1948.
} 
lieve this survey gives a valuable sampling. Campbell found that 40 per cent of the colleges have no demonstration schools on their campuses, and, of the schools that do exist, there are nearly twice as many elementary schools as high schools. Presumably, the colleges without model schools make arrangements for their students to do practice, teaching in nearby public or private schools.

Every demonstration school should have its own separate library, which should be specifically provided for in the budget of the central library. There should be a trained young people's or children's librarian in charge, and the library should be supervised by the college librarian.

The demonstration school should have a library that will not only serve the reference and recreational needs of the pupils, but one which will also provide an opportunity for the college students to see children actually using a library in an actual learning situation. In this way the students will learn at first hand how to make effective use of their own school libraries after they graduate and assume teaching positions.

The model school library should be a model in every way. In addition to having a trained librarian and a well-selected book collection which receives an adequate supply of new titles and replacements, the library should be housed in attractive, wellarranged, well-lighted and well-ventilated quarters. There should be sufficient chairs and tables of the proper types, and there should be a card catalog, vertical file cabinet, bulletin boards, dictionary stand, adjustable shelving for books, magazine rack, newspaper poles and all of the other things which we should like to see in all of our school libraries. Of course, the books should be properly classified and cataloged, and the charging system should be an efficient one.

Lowell ${ }^{8}$ maintains that the college students should familiarize themselves with children's literature by reading the books in the demonstration school library. But Fairchild's ${ }^{9}$ report shows that 19 per cent of the teachers colleges in the United States actually have in their buildings separate rooms devoted to collections of children's literature. A great many other libraries have such collections shelved in their general bookstacks.

4. No group of undergraduate students needs to become more thoroughly familiar with the operation of a library and with its various services than do those who are preparing themselves to become teacherlibrarians or who propose to enter a graduate library school upon the completion of their undergraduate course. These students need to attain to wide familiarity with good books and other materials and to learn some of the basic aspects of reference work and research. The students will also need to acquire a knowledge of the principles of library administration, as well as the fundamentals of cataloging and accessioning and the other "technical processes."

It is the responsibility of the library staff to see that instruction in library science is provided for all prospective librarians who desire it. The teaching can best be done by a qualified, full-time professor of library science, but where such a teacher is not available, the library staff should undertake to provide the necessary instruction. ${ }^{10}$

5. Since there is a growing demand that all high school teachers, especially adminis-

\footnotetext{
${ }^{8}$ Lowell, M. H. "The Training School Library in a Teacher-Training Institution." Library Journal, 6r :445, June $\mathrm{x}, \mathrm{1} 936$

${ }_{9}^{9}$ Fairchild. Op.cit. p. 63

${ }^{10}$ In addition to the information received in formal classes, prospective librarians can obtain a great deal of useful knowledge and practical experience by serving student-assistants in the teachers college library or in the demonstration school library.
} 
trative and supervisory officers, have the master's degree, the teacher whose formal education ends with an A.B. degree is considerably handicapped. As a result of this situation, an increasing number of teachers colleges throughout the country are adding a fifth year. Already more than one-third of them offer graduate work.

The presence of a graduate school emphasizes the importance of the demonstration school on the campus. And the graduate school affects the library by demanding the services of a highly-trained and scholarly reference staff to work with and assist the students. In addition, the library must provide extensive reference materials and the better secondary sources. In the fields in which special research work is offered, source material must be provided. ${ }^{11}$ As a concomitant to graduate work, open stacks are essential.

6. and 7. The last two points, correspondence and extension courses and service to alumni, can be considered together.

11 "Qualitative Standards for a Teachers College Library." Twenty-Sixth Yearbook of the American Association of Teachers Colleges. Oneonta, New York, American Association of Teachers Colleges, 1947. p. $130-35$.
Follow-up educational services of various kinds must be provided to the graduates of a teachers college who are out in the teaching field. And, whether these services involve the supplying of materials to an alumnus for use in his own teaching, or whether they involve the provision of opportunities for correspondence work or the provision of actual classroom-type lectures to the alumni and to others through organized extension courses-in any event, the effectiveness of these follow-up educational activities will depend to a large extent upon the full cooperation and assistance of the library staff.

We may summarize by stating that the teachers college is a relatively new type of professional school that has achieved a phenomenal development during the past 25 years; and that, because the teachers college performs the dual role of developing a student's entire personality while imparting information concerning the technique of teaching, the teachers college library must perform all of the functions customarily performed by a college library, and must, in addition, provide various special services.

\section{Serial Titles Newly Received}

The Library of Congress issued in January the first issue of Serial Titles Newly Received to meet the need of librarians, scholars and research workers for information about serials in their fields of interest. Initially, only titles received by the Library of Congress will be included, but it is hoped that the list can be expanded to include additional titles reported from other sources. Nevertheless, the titles received by the Library of Congress alone which are new to its collections are expected to total more than 20,000 in the course of the year, and these probably represent a large proportion of the new titles available in this country.

The continuation and expansion of this publication are of course dependent upon the support it receives in terms of advance subscriptions placed. The number of subscriptions will also determine the price. It is planned to publish the list in monthly issues and an annually cumulated volume. If sufficient support and cooperation can be secured, it will be possible to include additional locations for each title in the annual cumulated volume in addition to the inclusion in the monthly issues of titles reported by other libraries. It will also be possible to issue a cumulation arranged by subject, if enough subscriptions are received.

The Library of Congress needs the full support of librarians in this project. If your library plans to subscribe, do so now. Send subscriptions to the Card Division, Library of Congress, Washington 25, D.C. 